\title{
PREVENTION OF LEARNING DISABILITIES IN PRE-SCHOOL CHILDREN
}

\author{
Sarmite Tubele \\ University of Latvia, Latvia
}

\begin{abstract}
The article is devoted to revealing the possibilities of preventing learning disabilities in pre-school children. Early intervention is crucial to manage school failure and loss of self-confidence in children. Research is topical, as the number of children with mixed developmental disabilities and later, at school age - learning disabilities - is increasing. Some pre-school children may have various developmental disabilities, including mixed developmental disabilities, which present a whole spectrum of different problems that cannot solve themselves. If they do not receive help, these children will be diagnosed with lasting learning disabilities by reaching school age, and that can lead to a number of hardships for the pupils. Lessening or resolving these hardships will require a lot more effort to not inflict damage on the child's self-confidence and future life quality.

The aim of the study is to determine the knowledge of teachers about children with mixed developmental disabilities, their difficulties, and possibilities of recognizing early signs of problems.

Methodology: the research was carried out using literature review and questionnaire for pre-school teachers.

Results were not surprising - many teachers are not aware of mixed developmental disabilities; these disabilities are diagnosed alongside speech and language problems, and the number of these is increasing. The results are significant, and it is a possibility for speech therapists and special education teachers to create a curriculum for teachers to deal with these children to lessen problems.
\end{abstract}

Keywords: Learning disabilities, mixed developmental disabilities, preschool children, prevention, speech therapy.

\section{Introduction}

Preschool children turn into pupils imperceptibly. It does not happen in a single day. Even though competency-based learning offers children the possibility to develop on their own, the teacher needs to be very knowledgeable in order to support and, in a way, guide this process. The Skola 2030 [School 2030] documents offer various suggestions for organizing the 
education process in preschools. They offer a preschool education program (Miesniece, n. d.) which analyses the education process in three stages for a number of education areas - language, social, civic, and cultural understanding, the art of self-expression, natural sciences, mathematics, technologies, health, and physical activities. They also include a detailed plan for content and approach of teaching and give methodological advice for preschool teachers (Olin,a \& Rolanda, n. d.). General recommendations for education for modern competencies (Namsone \& Olina, n. d.) are given. Even though a preschool child's development can happen at an individual rate, the preschool teacher evaluates the child's accomplishments and observes his actions when acquiring transversal skills, habits, and basic skills of the previously mentioned education areas (Miesniece, n. d.). A huge emphasis is placed on the child's self-assessment and activity while inquiring about the world and learning at the same time. After finishing this level of education, the child has achieved the necessary development to start learning in school. There needs to be a specific level of readiness, also called school readiness. Not every child has the same level of success, and it is determined by his individual developmental characteristics, which speech therapists, special education teachers, and skillful preschool teachers can help with.

\section{Methodology}

The research used a review of theoretical literature that helps to understand the problem and its topicality and justifies the necessity and importance of the research. Scientific articles were sourced from Google Scholar (keywords learning disabilities, prevention, early prevention, developmental delays were used); eight articles were analysed in theoretical findings. Various books on preschool children development and school readiness were also used. One of the survey methods used was a questionnaire of preschool teachers (54 respondents participated; random sample) in order to determine whether teachers know what mixed developmental disabilities are and whether they are ready to work with these children. The research questionnaire included multiple questions, but the article presents and analyses only those answers that describe their understanding of characteristics of mixed developmental disabilities and recognizing them. The data were anonymos and analysed in an aggregated manner.

\section{Results}

The topic of children's school readiness has been addressed by several researchers and scientists, and they have focused on various developmental areas, determining what a child should know and be able to do when 
starting school (Gavrina et al., 2006; Kaņepēja, 2003; 2012; Бабкина, 2006; Дубровина, 2001; Гуткина, 2000; 2007; Екжанова, 2007). Although they look at abilities in the areas of language, mathematics, social knowledge, physical development, and other areas, it does not differ in essence from the seven education areas for preschool that have been put forth in the latest research (Miesniece, n. d.). The difference lies in evaluation and definitions, but one thing is clear - the child needs to be ready to progress from play activities to learning activities, to begin a different kind of didactic communication, and to learn the abilities and knowledge provided in school.

However, sometimes this progression is not that simple (Bethere, 2013), and the child needs help to prepare for school (Craft, 2020; Kauce, 1971; Каше, 1985), as not everyone is capable of advancing on the path of learning by themselves. An important topic is the adjustment of children in first grade, what affects it, and how we can help (Āboltina, 2014; Князева, 2007; Костяк, 2008), because delayed development hinders the process of adjustment.

At school age, we can recognize learning disabilities which are represented by a specific heterogeneous group of children (Tūbele et al., 2013b; Turkington \& Harris, 2006). They have difficulty following the school's education program without support (Tūbele, 2019). These children do not appear suddenly, the school's educational process is not the beginning of their hardships. It can often be noticed at preschool age, especially if the child has a speech or language disability. The number of these children is relatively big, and it has a tendency of increasing (Tomele, 2018). In more severe cases, when the problem concerns not only pronunciation, but also the process of learning a language and using it in everyday communication, children need regular, specially organized speech therapy sessions and constant support (Law et al., 2017; Tūbele et al., 2013a; Tūbele, 2019). This seemingly creates a contradiction, as the work is competency-based; however, it is important to understand that support measures allow these children to catch up with their peers in a relatively short time and become learners that are just as successful (Skorek, 2009). Without this kind of help, they will not be able to successfully develop by themselves. This support is also necessary for children with mixed developmental disabilities (F 83), when the problem concerns not just a single developmental area, but, alongside language disabilities, problems are present in preschool with learning arithmetic skills, the development of cognitive abilities is hindered, and there is a lack of planning of purposeful movement (Tūbele, 2019; Turkington \& Harris, 2006). This also determines the formation of diagnoses - mixed specific developmental disorders (F83) (ICD-10, 2021); later on, at school age - mixed disorder of scholastic skills (F81.3) (ICD-10, 2021). 
Mixed specific developmental disorders is a residual category for disorders in which there is some mixture of developmental disorders of speech and language, school skills, and motor functions; nevertheless, none of these is dominant enough to form a main diagnosis. This mixed category should only be used if there is an extensive overlap with all of these circumscribed developmental disorders. The disorders are usually associated with a certain degree of general impairment of cognitive functions; it should therefore be used if there are malfunctions that meet the criteria of two or more categories of F80; F81 and F82 (Tūbele et al., 2013a). It is very important to notice these impairments early on, at preschool age, and to start corrective developmental activities that could lessen the level and manifestations of the impairment (Fielding-Barsley, 2006; Rice et al., 2014). These would be preventive measures, and many researchers emphasize these and offer significant solutions (Batista \& Pestun, 2019; Craft, 2020; Healy, 2009; Pesova, Sivevska, \& Runceva, 2016). Early diagnostics by observing preschool children is one of the most important measures (Fielding-Barsley, 2006; Pesova et al., 2016). Speech therapists and special education teachers know of the possible measures, but the age when corrective activities are started is a little belated (in Latvia it is usually 5 years of age), when many undesirable and incorrect habits (for example, distorted pronunciation, substitution and mistaking of sounds, etc.) have already been fixated and are harder to correct. Gaps in education require more effort from the teacher, lowered interest or lack of interest in learning and unwillingness to make an effort to overcome hardships requires creativity and a special approach from the teacher. In order to achieve this, it is necessary to diagnose not just the deficiencies and weak points in a child's development; a crucial factor for success stories is the child's strong points and interests (Tūbele, 2019).

Well-organized support measures in preschool will be a basis for a more successful overall development. For specialists (speech therapist, special education teacher, psychologist), the question is not the child's hardships and problems; it is rather a question of finances - at which point they can begin work with a child who has a speech or language disability, or even mixed developmental disabilities.

The knowledge of preschool teachers about mixed developmental disabilities and ways of understanding them and helping children was researched in the master's thesis Cooperation between special education teacher and preschool teacher in mixed developmental disorder reduction for 5-6-year-old children by M. Osmane. 54 preschool teachers were interviewed, and among other questions, there was a question about mixed developmental disability characteristics in preschool children and whether those had been observed (Table 1). 
Table 1. Knowledge of preschool teachers about the characteristics of mixed developmental disabilities

\begin{tabular}{|l|l|l|l|}
\hline Observed characteristics & Never & Rarely & Regularly \\
\hline Speech and language impairments & 5 & 7 & 42 \\
\hline Motor difficulties & 6 & 30 & 18 \\
\hline Inhibited mental processes & 7 & 23 & 24 \\
\hline Impaired learning ability & 4 & 22 & 28 \\
\hline $\begin{array}{l}\text { Impaired understanding of space, time, cause } \\
\text { and effect }\end{array}$ & 11 & 30 & 13 \\
\hline
\end{tabular}

The data presented in the table shows that $78 \%$ or 42 (out of 54 ) preschool teachers have regularly observed speech and language impairments (specific speech articulation impairments, expressive language impairments, receptive language impairments, and/or phonological development impairments) amongst their pupils. Out of 54 respondents, $52 \%$ or 28 have observed impaired learning ability (specific reading impairments, spelling impairments, and/or arithmetic ability impairments). Out of 54 respondents, $44 \%$ or 24 have observed inhibited mental processes (deviations in the development of emotions and perception, as well as memory, imagination, and understanding; inhibited development of emotions and will; slow work pace; difficulty concentrating; quick fatigue). Out of 54 preschool teachers, $33 \%$ or 18 have regularly observed motor difficulties (weak or underdeveloped fine and/or gross motor skills) amongst their pupils. Out of 54 preschool teachers, $24 \%$ or 13 have observed impaired understanding of space, time, cause and effect (difficulty with orientation in space, plane, time; difficulty separating the important and less important, determining the sequence of events) (Osmane, 2020).

Preschool teachers have observed various impairments in their pupils, and, although they seek advice from the available specialists, they would also benefit from the knowledge of how to help these children.

\section{Discussion}

It would be beneficial to develop a corresponding further education program for preschool teachers in order to give them the opportunity to recognize possible disabilities early on and to create a further plan of action. In this way, together with a special education teacher and a speech therapist, they could support the child with mixed developmental disabilities and ensure probable successful development. It is advisable to include parents in the process of corrective developmental activities, especially in the stage of consolidating learned abilities, as this will not only further the child's 
development, but also improve the bond and mutual understanding with the child. Teacher's knowledge of children with mixed developmental disabilities is superficial, early signs and difficulties of these children are not always seen.

\section{Conclusions}

Language disorders are mainly recognized the number of which tends to increase. Teachers have difficulty linking various symptoms and different manifestations of problems and finding solutions to help.

Children with mixed developmental disabilities present with irregular development in several areas; overall development is also inhibited and does not correspond with the child's actual age.

In order to acquire new knowledge and abilities, children with mixed developmental disabilities need more time, demonstration methods, and repetitiveness.

These children easily accept and use the help of adults, and that is a good indicator and a factor that contributes to development.

Strong points are the basis of development for all children; therefore, it is important to determine and use them when planning and carrying out lessons.

Professional measures need to actively include a speech therapist and a special education teacher, as well as the collaboration of all included parties.

Analysis of theoretical literature allows for the conclusion that solutions to the problems are possible, but the results of the questionnaire show that preschool teachers have insufficient understanding and knowledge of mixed developmental disabilities.

Recognizing the problems and starting corrective developmental activities early on is an important preventive measure in order to ensure less manifested learning disabilities at school age.

It is necessary to further educate preschool teachers about recognizing mixed developmental disabilities and using corrective developmental methods in their daily work.

\section{References}

Āboltiña, L. (2014). 7-gadīgu bērnu sociālā adaptēšanās skolai 1. klasē. [Social Aaaptation of 7-year old children to school in the $1^{\text {st }}$ grade] Promocijas darbs. Rìga: Latvijas Universitāte.

Batista, M., \& Pestun, M. S. V. (2019). The RTI Model as a prevention strategy for learning disorder. In: Psicologia Escolar e Educacional. 2019. v. 23. e205929 http://dx.doi. org/10.1590/2175-35392019015929 
Bethere, D. (2013). Pārejas posms pirmsskola - pamatskola. [Transition stage pre-school primary school] Ríga: RaKa.

Craft, D. (2020). Can Learning Disabilities be Prevented? Downloaded from: http:// diannecraft.org/can-learning-disabilities-be-prevented/

Fielding-Barnsley, R. (2006). Early Prevention of Learning Disabilities: Comments on Lyytinen and Erskine, and Fuchs. Downloaded from: http://www.child-encyclopedia.com/ learning-disabilities/according-experts/early-prevention-learning-disabilities-commentslyytinen-and

Gavrina, S., Kutjavina, N., Toporkova, I., Ščerbiņina, S., Četvertakovs, K., Klarina, L,., Kuzmenko, J. (2006). Bērna attistibai. Gribu uz skolu (5-6 gadi). Palīdzēsim bèrniem sekmigi uzsākt skolas gaitas. [Child development. I want to go to school (5-6 years). We will help children to start school successfully] Rīga: Zvaigzne ABC.

Healy, J. M. (2009). Different learners: identifying, preventing, and helping your children's learning problems. USA: Simon \& Schuster Paperbacks.

ICD-10 (2021). International Classification of Diseases: Pervasive and specific developmental disorders F80-F89. Downloaded from: https://www.icd10data.com/ICD10CM/ Codes/F01-F99/F80-F89

Kaņepēja, R. (2012). Gatavība skolai. [Readiness for school] No: Kaņepēja, R., Lieǵgeniece, D., Mangule, I., Ukstiņa, R., Dzintere, D., Stangaine, I., Mikelsone, I., Millere, I., Platpers, A., Gaugere, Z. Ceẹ̄a uz skolu: bērnu sagatavošana pamatizglitïbas ieguvei. [Towards school:preparing children for primary education] Rīga: Zvaigzne ABC, 6.-15. lpp.

Kaņepēja, R. (2003). Kas ir gatavība skolai. [What is readiness for school] No: Kaņepēja, R., Liegeniece, D., Černova, E., Dzintere, D., Pučure, I., Ukstiņa, R., Mik̦elsone, I., Suruda, I., Giluča, V. Es gribu iet skolā. [I want to go to school] Rīga: Puse Plus, 9.-12. lpp.

Kauce, A. (1971). Bērnu vispārīgā sagatavošana skolai.[General preparation of children for school] No: Biezā, D., Kauce, A., Kromāne, Dz., Līduma, M. Bērnu sagatavošana skolai. [Preparing children for school] Rīga: Zvaigzne, 6.-29. lpp.

Law, J., Charlton, J., Dockrell, J., Gascoigne, M., McKean, C., \& Theakston, A. (2017). Early Language Development: Needs, provision, and intervention for preschool children from socio-economically disadvantage backgrounds. A report for the Education Endowment Foundation October 2017. Downloaded from: https://educationendowmentfoundation. org.uk/resources/publications/early-language-development

Miesniece, A. (proj. vad.) (n. d.). Pirmsskolas mācību programma: Skola 2030. [Preschool curriculum: School 2030] Downloaded from: https://mape.skola2030.lv/resources/10

Namsone, D. \& Oliña, Z. (n. d.). Izglītība mūsdienīgai lietpratībai: mācību satura un pieejas apraksts. [Education for modern skills: a description of content and approach of learning] Downloaded from: https://static.lsm.lv/documents/ge.pdf

Oliṇa, Z. \& Rolanda, L. (n. d.). Mācību satura un pieejas plānošana: Metodiskie ieteikumi pirmsskolas skolotājam: Skola 2030. [Planning of curriculum and approach:Methodological recommendations for pre-school teachers. Shool2030] Downloaded from: https://mape.skola2030.lv/resources/87

Osmane, M. (2020). Speciālās izglïtibas skolotāja un pirmsskolas pedagoga sadarbïba jauktu attistibas traucējumu mazināšanai 5-6 gadus veciem bērniem: Diplomdarbs. [Cooperation between special education teacher and preschool teacher in mixed developmental disorders reduction form 5-6 old children] Riga: University of Latvia.

Pesova, B., Sivevska, D., \& Runceva, J. (2014). Early Intevention and Prevention of Students with Specific Learning Disabilities. In: Procedia - Social and Behavioral Sciences 149 (2014) 701-708, ELSEVIER Downloaded from: www.sciencedirect.com 
Rice, S. E., Braun, K.V.N., Kogan, M. D., Smith, C., Kavanagh, L., Strickland, B., \& Blumberg, S. J. (2014). Screening for Developmental Delays Among Young Children National Survey of Children's Health, United States, 2007. Downloaded from: https:// www.cdc.gov/mmwr/preview/mmwrhtml/su6302a5.htm

Skorek, E. M. (2009). Life quality in children with speech disabilities. Krakow: Impuls.

Tomele, G. (2018). Runas un valodas attīstības multistrukturālais modelis bērnu

valodas traucējumu prevencijā Montesori pedagoǵijas aspektā. [Multistructural model of speech and language development in children in the prevention of language disorders in the aspect of Montessori pedagogy] Downloaded from: http://DOI.ORG/10.22364/ IDTCDD.2018.08

Tūbele, S. (2019). Valodas traucējumu novērtēšana. [Assessment of language disorders] Rìga: RaKa.

Tūbele, S., Landra, T., Šūmane, I., Burčaka, M., Laganovska, E., Kušnere, S., Vīgante, R. (2013a). Metodiskais materiāls pedagogiem darbam ar izglitojamiem ar jauktiem attistibas traucējumiem. Rokasgrāmata. [Methodological material for teachers to work with students with mixed developmental disabilities. Handbook] Rīga: VISC.

Tūbele, S., Landra, T., Šūmane, I., Burčaka, M., Laganovska, E., Kušnere, S., Vīgante, R. (2013b). Metodiskais materiāls pedagogiem darbam ar izglìtojamiem, kuriem ir mācīšanās traucējumi un redzes traucējumi. Rokasgrāmata. [Methodological material for teachers to work with students with learning disabilities and low vision. Handbook] Rìga: VISC.

Turkington, C., Harris, J. (ed). (2006). The Encyclopedia of Learning Disabilities. New York: American Bookworks.

Бабкина, Н. В. (2006). Оценка психологической готовности детей к школе: Пособие для психологов и специалистов коррекционно-развивающего обучения. [Assessment of the psychological readiness of children for school: A guide for psychologists and specialists in correctional and developmental education] Москва: Айрис Пресс.

Дубровина, И. В. (ред.) (2001). Готовность к школе: Развивающие программы. [Readiness for school: Develping curriculum] Москва: Академический Проект.

Гуткина, Н. И. (2000). Психологическая готовность к школе. [Psychological readiness for school] Москва: Академический Проект.

Гуткина, Н. И. (2007). Психологическая готовность к школе. [Psychological readiness for school] Санкт-Петербург: Питер.

Екжанова, Е. А. (2007). Методика исследования готовности детей к школьному обучению. [Research methodology of children's readiness for schooling] Санкт-Петербург: Каро.

Каше, Г. А. (1985). Подготовка к школе детей с недостатками речи. [Preparing children with speech impairments for school] Москва: Просвещение.

Князева, Т. Н. (2007). Психологическая готовность ребёнка к обучению в основной школе. [Psychological readiness of the child to study in the mainstream school] СанктПетербург: Речь.

Костяк, Т. В. (2008). Психологическая адаптация первокласников. [Psychological adaptation of the first graders] Москва: Академия. 